PRZEGLĄD BIBLIOTECZNY 2020 z. 1

PL ISSN 0033-202X

AGNIESZKA WOLAŃSKA

Biblioteka Centrum Studiów Niemieckich

i Europejskich im. Willy'ego Brandta

Uniwersytetu Wrocławskiego

e-mail: agnieszka.wolanska@uwr.edu.pl

\title{
USŁYSZEĆ NIEWYPOWIEDZIANE. DOSTRZEC NIEWIDOCZNE. TECHNIKI UX (USER EXPERIENCE) W BADANIACH UŻYTKOWNIKÓW BIBLIOTEK.SZANSE I PERSPEKTYWY
}

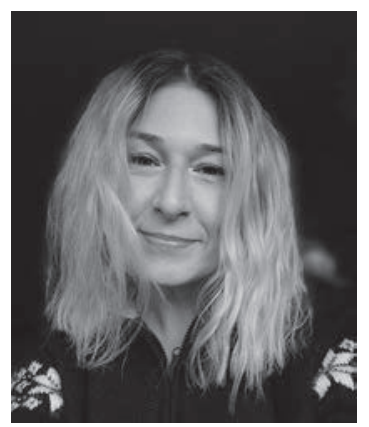

Kustosz dyplomowany, magister bibliotekoznawstwa i informacji naukowej na Uniwersytecie Wrocławskim. W latach 2003-2015 pracownik Biblioteki Politechniki Wrocławskiej, obecnie kieruje Biblioteką Centrum Studiów Niemieckich i Europejskich im. Willy'ego Brandta na Uniwersytecie Wrocławskim. Członek redakcji „Biuletynu EBIB”. Autorka kilkunastu publikacji z dziedziny bibliotekoznawstwa, m.in. Metoda etnograficzna i UX usability testing w badaniach użytkowników bibliotek. Badania jakościowe kontra kult statystyki. „Annales Universitatis Paedagogicae Cracoviensis. Studia ad Bibliothecarum Scientiam Pertinentia" 2018, T. 16, s. 220-235.

SŁOWA KLUCZOWE: Biblioteka. Badania użytkownika. Badania jakościowe. UX. User experience. Doświadczenia użytkownika. Techniki UX. Mapowanie kognitywne. Mapowanie behawioralne. Sortowanie kart. Sonda kulturowa. Wywiad. Badanie postaw. Badanie behawioralne. Touchstone tours. Obserwacja.

ABSTRAKT: Teza /cel artykułu - Opieranie swojej wiedzy dotyczącej użytkownika biblioteki na dość powszechnie stosowanych badaniach ankietowych lub wywiadach standaryzowanych w wielu przypadkach nie daje pełnej wiedzy o jego prawdziwych intencjach i potrzebach. Według antropolożki Margaret Mead „To co ludzie mówia, to, co robia, i to, 
co mówia, że robia, to trzy całkowicie różne rzeczy". Artykuł prezentuje techniki UX, za pomocą których udaje się poznać niewidoczne i niewypowiedziane potrzeby użytkowników oraz stawia pytania o możliwość zaimplementowania takich badań w Polsce. Metody badań - Dokonano analizy literatury anglojęzycznej i polskiej w zakresie UX z ostatnich 10 lat, odwołując się również do starszych publikacji z zakresu etnologii i antropologii, które to dziedziny, jak wykazano, mają zasadniczy związek z badaniami jakościowymi. Kwerenda wykazała, że tematyka UX w kontekście bibliotek pojawia się głównie w badaniach dotyczących instytucji zagranicznych, a w Polsce jedynie sporadycznie. Na podstawie źródeł przedstawiono przegląd technik UX w ujęciu pojęciowym wraz z przykładami. Przemyślenia poparto własnym doświadczeniem pozyskanym podczas warsztatów UXLibs w Sheffield w 2018 roku. Wyniki i wnioski - Przedstawione techniki sprawdzają się w badaniach bibliotek na świecie, a uzyskane w ten sposób dane mogą być doskonałym uzupełnieniem badań ilościowych, do tej pory przeważających w polskich bibliotekach.

Biblioteki to instytucje usługowe, które zaspokajanie potrzeb informacyjnych, kulturalnych, literackich, społecznych i wielu innych ${ }^{1}$ swoich użytkowników mają wpisane w swoją misję. W literaturze fachowej istnieje ogromna liczba artykułów dotyczących prób ich zdefiniowania (np. Kołakowska, 2017; Kamińska, 2008) oraz badań satysfakcji użytkowników z usług bibliotecznych (np. Derfert-Wolf, Sobielga, Strzelczyk, Zawałkiewicz, 2018). Wiele z publikacji zdaje się jednak jedynie „dotykać" problemu z bezpiecznej odległości, przedstawiając pozyskiwaną wiedzę jako wynik zadawanych użytkownikowi pytań dotyczących korzystania przez niego z usług bibliotecznych, przyjmujący najczęściej formę liczb i wskaźników. Wydawałoby się, że jest to właściwy kierunek. Obie strony mają poczucie spełnionego obowiązku: użytkownik udziela odpowiedzi na postawione $\mathrm{w}$ ankiecie pytania, biblioteka analizuje jego odpowiedzi i uzyskuje informacje na temat oceny jakości swoich usług, słabe punkty działalności instytucji wskazane przez badanego mogą być poprawione.

Mimo tak licznych opracowań dotyczących badania potrzeb użytkownika można jednak odnieść wrażenie, że nadal o naszym użytkowniku wiemy niewiele poza tym, co sam nam chce powiedzieć.

Podkreślić należy, że pozyskiwana z badań ankietowych wiedza jest niewątpliwie cenna i z pewnością wzbogaca wiedzę o usługobiorcach biblioteki. Nie chodzi o to, aby ją odrzucać, ale raczej uzupełniać o nowe perspektywy i sposoby badania użytkowników.

Oprócz pozyskiwania informacji na temat satysfakcji korzystania z bibliotek i ich zbiorów, warto poszerzyć badania o techniki, które dostarczą nam wiedzy szerszej, niż wspomniane badania ankietowe i wywiady standaryzowane. Być może pokażą one, że często założenia, przyjmowane przez bibliotekarzy, dotyczące motywów działania użytkowników mogą być błędne. Dlatego też motto każdego bibliotekarza powinno brzmieć

\footnotetext{
${ }^{1} \mathrm{~W}$ ostatnich latach pojawia się tak wiele nowych usług świadczonych przez biblioteki, że trudno wręcz pokusić się o zawężenie tej listy.
} 
„Nie jestem swoim użytkownikiem”. Oznacza to, że bez względu na to, $\mathrm{w}$ jaki sposób użytkownik korzysta $\mathrm{z}$ naszych usług, powinniśmy powstrzymać się od ocen.

Również inne dane ilościowe, takie jak liczba wypożyczeń, ściągnięć plików elektronicznych, wyświetleń strony czy wreszcie obserwatorów instytucji w mediach społecznościowych są niejednokrotnie traktowane jako wyznacznik spełniania potrzeb użytkowników, a przecież nie dostarczają one odpowiedzi na temat tego, jakim doświadczeniem jest dla nich kontakt z biblioteką i jej zasobami (Appleton, 2016). Można do opisu tej sytuacji wykorzystać następującą analogię: „(...) O ile wyniki badań ilościowych porównać można do fotografii z lotu ptaka, to wyniki badań jakościowych są filmem kręconym z poziomu widzenia człowieka. (...)" (Kostera, 2003, s. 25). Takie spojrzenie jest niezwykle cenne i odsłania więcej, niż dostarczają same tylko dane liczbowe. Powyższa analogia wydaje się tym bardziej słuszna, że User Experience (UX) i jego techniki pojawiają się literaturze właśnie w kontekście badań jakościowych w etnografii, antropologii czy psychologii (Nunnally, Farkas 2017, s. 62).

User Experience to badania, które „(...) obejmują wszystkie aspekty interakcji użytkownika z firma, jej usługami i produktami. (...)" (Norman, Nielsen, 2019). Projektowanie [usług] zgodne z UX to takie, w wyniku którego interakcja użytkownika z produktem wywołuje pozytywne doświadczenie (Lipiec, 2007). Początkowo termin ten stosowany był w odniesieniu do relacji człowiek-komputer (Lipiec, 2007), ale obecnie cechuje go interdyscyplinarność na pograniczu antropologii, psychologii, ergonomii, marketingu i innych dziedzin, do których może być adaptowany. UX wpisuje się także w koncepcję ekonomii doświadczeń, która definiuje „projektowanie i dostarczanie doświadczenia jako niezależnej wartości” (Wójcik, 2016, s.104). Funkcjonalność i użyteczność jakie leżą u podstaw UX nie są obecnie jedynymi atrybutami UX. Współcześnie UX obejmuje całość podejmowanych działań, których celem jest osiągnięcie satysfakcja użytkownika z usługi. Te działania wymagają obrania określonej drogi postępowania, aby dowiedzieć się jakie są potrzeby użytkownika. W tym celu stosuje się koncepcję myślenia projektowego (design thinking), którego elementami są immersja (poznanie problemu z perspektywy klienta), ideacja (opieranie się na wynikach immersji i tworzenie pomysłu projektu) oraz prototypowanie (stworzenie prototypu i testowanie) (Mościchowska, Rogoś-Turek, 2019 s. 36). Sama koncepcja myślenia projektowego nie będzie przedmiotem niniejszego artykułu, ale jest niezbędna do odnotowania, ponieważ techniki UX występują w każdej z jej części składowych.

Idea stosowania technik UX w bibliotekach nie jest przypadkowa. Bibliotekarze ze swoją wszechstronną wiedzą i umiejętnościami w zakresie architektury informacji są wręcz predestynowani do stania się specjalistami w tym zakresie (Nunnally, Farkas, 2017). Tym bardziej zatem badania 
UX powinny wpisać się w działalność biblioteki jako stały element codziennej pracy.

Badania doświadczeń/wrażeń użytkownika biblioteki mogą dotyczyć jego kontaktu z usługą w przestrzeni fizycznej oraz wirtualnej. Od tego, jaką przestrzeń chcemy objąć badaniem, zależy dobór odpowiednich technik, które mogą być stosowane oddzielnie lub uzupełniać się. Należy jednak zaznaczyć, że przedstawione $\mathrm{w}$ artykule techniki nie wyczerpują listy potencjalnych możliwości, a jedynie są próbą zaprezentowania takich $\mathrm{z}$ nich, które zostały z sukcesem zastosowane w praktyce bibliotecznej.

UX obejmuje zarówno badania behawioralne (dotyczące zachowań, bez dokonywania ich oceny), jak i badania postaw (wyrażania opinii, myśli czy odczuć). Oba podejścia są używane komplementarnie.

\section{BADANIA BEHAWIORALNE}

\subsection{OBSERWACJA}

Obserwacja jest jedną z podstawowych metod etnografii. Jest to metoda o tyle trudna, że wymaga od badacza dużej dozy obiektywizmu. Badacz może być jednocześnie uczestnikiem badania (obserwacja uczestnicząca) bądź jest obserwatorem zewnętrznym (obserwacja nieuczestnicząca). Oba rodzaje niosą za sobą określone implikacje (Kostera, Krzywokrzeka, 2012). Obserwacja jest metoda, która pozwala dostrzec zachowania obiektów $\mathrm{w}$ ich naturalnym środowisku, dająca możliwość wyodrębnienia reguł i zasad, jakie są stosowane. Stosunkowo nieduży wpływ badacza na przedmiot badań przekłada się na dość dobre odwzorowanie rzeczywistości (Mościchowska I., Rogoś-Turek B. 2019, s.137) Przykładem stosowania obserwacji jako części projektu UX w bibliotece jest Biblioteka University of the Arts w Londynie (Appleton, 2017), która wykorzystała obserwację studentów i sposobów ich poruszania się w przestrzeni biblioteki, jednocześnie obserwując konkretne miejsca w bibliotece i to, w jaki sposób są wykorzystywane przez użytkowników.

\subsection{MAPOWANIE BEHAWIORALNE}

Technika ta polega na obserwacji i analizie zachowania użytkowników w rzeczywistej przestrzeni bibliotecznej przy pomocy obserwatorów bądź urządzeń (np. kamer). Dane, jakie zostają w ten sposób pozyskane, są nanoszone na mape pomieszczeń odzwierciedlającą sposób, w jaki użytkownicy korzystają z biblioteki, a także gdzie tworzy się tzw. desire line / desire path, czyli trasa, którą użytkownicy poruszają się najczęściej (Priestner, 2018). Uzyskana mapa pokazuje także strefy, które nie są używane, z jakichś powodów nie spełniające swojej roli lub też takie, które są nadmiernie obłożone. Takie wnioski są niezwykle cenne i pozwalają zoptyma- 
lizować przestrzeń, dostosowując ją do realnych potrzeb użytkowników. Po dokonanych modyfikacjach można powtórzyć badanie, sprawdzając, w jaki sposób zmieniło się korzystanie użytkownika z przestrzeni.

Mapowanie behawioralne jest dość często stosowane (np. Gullikson, 2016), nie tylko w odniesieniu do przestrzeni biblioteki, ale przy projektowaniu wszelkiego rodzaju przestrzeni publicznych (Poniatowski, 2012) lub obiektów handlowych. Jeżeli zaś chodzi o obiekty biblioteczne to nadzwyczaj interesującym przykładem mapowania behawioralnego są badania przeprowadzone w Duńskim Uniwersytecie Technicznym (DTU) (Hald, Just Nordholdt, 2018), w którym oprócz obserwatora liczącego ile osób podchodzi do bibliotecznej lady, jak długo oczekują na bibliotekarza oraz jakie są ich reakcje, zastosowano kamery do analizy ruchu użytkowników (nie rejestrujące zapisu wideo, a jedynie ruch osoby).

\subsection{TESTOWANIE FUNKCJONALNOŚCI}

Funkcjonalność stanowi podstawę UX. Jej podstawy to znajdowalność, wiarygodność dostępność i użyteczność (Morville, Rosenfed, 2003, s. 28). Można zatem powiedzieć, że funkcjonalność miejsca czy usługi jest na wysokim poziomie wówczas, kiedy użytkownik bez względu na to, jakie ma przygotowanie do korzystania z nich, umie sprawnie (bez ingerencji zewnętrznej) poruszać się w ich obszarze i otrzymuje dokładnie to, po co przyszedł. „Nie każ mi myśleć!” - tak o funkcjonalności stron internetowych pisze Steve Krug (Krug, 2003) i hasło to doskonale odzwierciedla ideę funkcjonalności w ogóle. Użytkownik powinien być zwolniony z myślenia na temat kolejności podejmowania kolejnych kroków, intuicyjność miejsca / usługi powinna w bezproblemowy sposób umożliwić mu przejście przez najbardziej nawet skomplikowane procesy. Testowanie funkcjonalności jest podstawą działalności podmiotów komercyjnych, takich jak instytucje usługowe czy sklepy internetowe. Jakie działania podejmuje się, aby przeprowadzać testowanie funkcjonalności?

Mogą to być zadania, które wykonuje użytkownik w oparciu o przygotowany scenariusz (np. wyszukaj książkę, znajdź czasopismo) i obserwacja jego kroków w celu sprawdzenia, czy jego droga do celu jest dokładnie taka, jaką założyliśmy projektując produkt czy usługę. W przypadku testowania usług elektronicznych dużym ułatwieniem jest użycie oprogramowania, które śledzi ruch na ekranie (np. Activity Monitor lub Camtasia), ale w połączeniu z prowadzeniem rozmowy z użytkownikiem (Friberg, 2017) i sprawdzaniem jego reakcji. Do testowania użyteczności można posłużyć się także badaniami eyetrackingowymi i facetrackingowymi (Jasiewicz, 2018).

Przykładem połączenia aspektów przestrzeni i świata cyfrowego jest badanie Atkins Library Ethnography Project - ALEP, przeprowadzone w Bibliotece J. Murrey Atkins (Wu, Lanclos, 2011), gdzie jednocześnie 
postanowiono zająć się zmianą aranżacji jednego z pięter biblioteki oraz zaprojektowaniem nowej strony www (Wolańska, 2018, s. 228-229). Uzyskane doświadczenia pozwoliły na spojrzenie na bibliotekę jak na przestrzeń, w której zmiany (w obu wymiarach) są naturalną konsekwencją zmieniających się potrzeb użytkowników.

\subsection{TOUCHSTONE TOURS ${ }^{2}$}

Jest to rodzaj wycieczki po bibliotece, w której w rolę oprowadzającego wciela się użytkownik, a oprowadzanym jest osoba prowadząca badanie. Skala takiego przedsięwzięcia zależy od organizatorów: może być to przekaz użytkownika na temat określonego miejsca w bibliotece (np. biurka, które zazwyczaj zajmuje), lub oprowadzenie bibliotekarza po wszystkich pomieszczeniach bibliotecznych. $W$ trakcie badania jest prowadzona rozmowa, tworzone są szkice, notatki, można także rejestrować całe działanie (Martin; Hannington, 2012, s. 84). Celem jest uzyskanie najbardziej subiektywnego punktu widzenia użytkownika i zebranie jak największej liczby informacji oraz sugestii dotyczących obszaru, w jakim się porusza użytkownik (Appleton, 2017, s. 72). Należy podkreślić, że ta technika może być również stosowana $\mathrm{w}$ świecie wirtualnym, np. do zbadania, $\mathrm{w}$ jaki sposób użytkownik korzysta z zasobów elektronicznych biblioteki, bądź katalogu (Stiles, 2017, s. 129). Przykładem zastosowania opisanej techniki jest m.in. badanie przeprowadzone w Bibliotece Uniwersytetu Guelph w Kanadzie, z którego raport jest dostępny w sieci (Mc Laughlin; Rayment, 2018).

\section{BADANIA POSTAW}

Badania postaw (attitudinal research) to badania oparte na punkcie widzenia badanych (Flick, 2010, s.23). Badania postaw dążą do uzyskania od użytkowników wypowiedzi, niekoniecznie nawet związanych z samymi usługami bibliotecznymi (choć tego oczywiście nie wykluczaja, jak pokażą poniższe przykłady).

\subsection{WYWIAD}

Technika dobrze znana, często stosowana w przypadku badań użytkowników. „Prowadzenie wywiadu jest procesem kierowania rozmową w celu zebrania informacji" (Angrosino, 2010, s. 88). Według tej definicji wywiad to rozmowa, a więc powinna mieć charakter otwarty, nie zamykająca się w sztywnych ramach, ale raczej stwarzająca możliwości

\footnotetext{
${ }^{2} \mathrm{Z}$ ang. touchstone: probierz, miernik, wskaźnik; tours: wycieczki, przechadzki [W literaturze termin występuje $\mathrm{w}$ liczbie mnogiej]. Z uwagi na trudność $\mathrm{w}$ dokładnym tłumaczeniu pozostawiono wersję oryginalną.
} 
swobodnej wypowiedzi (oczywiście w pewnych moderowanych przez prowadzącego wywiad ramach). Idealną formą wywiadu jest stosowany w badaniach terenowych (etnograficznych) wywiad niestandaryzowany i jednocześnie niestrukturalizowany. Oznacza to, że nie stosuje się takich samych pytań dla wszystkich badanych, a także nie precyzuje się ich w taki sposób, aby odpowiedź miała z góry przyjętą przez badającego formę (Kostera, Krzywokrzeka, 2012 s. 175).

$\mathrm{W}$ polskich bibliotekach dominuje stosowanie kwestionariuszy zamkniętych. Nawet aktualny Poradnik dla bibliotekarzy dotyczący badania satysfakcji użytkowników (Strzelczyk, Zawałkiewicz, 2018) wśród rekomendowanych metod wymienia jedynie standaryzowany kwestionariusz (Strzelczyk, Zawałkiewicz, 2018, s. 8), a możliwość modyfikacji pytań dotyczy jedynie różnic w funkcjonowaniu typów bibliotek. Tymczasem „(...) sekret dobrego wywiadu (...) polega na tym, aby podążać za tokiem wypowiedzi rozmówcy. To on lub ona decyduje, jakie wątki i w jakiej kolejności chce poruszyć. My powinniśmy zajmować jak najmniej przestrzeni w tej wymianie - słuchać i ograniczyć swoje wypowiedzi do minimum. (...)" (Kostera, Krzywokrzeka, 2012, s. 176). Standaryzowane kwestionariusze z pytaniami zamkniętymi nie dadzą nam wiedzy o użytkownikach, jaką przyniosłaby bezpośrednia rozmowa w formie otwartej. Nie oznacza to jednak, że prowadzący rozmowę zadawać ma przypadkowe pytania, a raczej posiłkując się przygotowaną listą zagadnień, moderować jej przebieg. Jednocześnie podkreślić należy, że prowadzenia wywiadu nie jest sprawą prostą.

Koncepcja badań etnograficznych $\mathrm{w}$ bibliotekach pojawia się w literaturze wielokrotnie (Asher, Miller, 2011; Lanclos, 2013), a jej techniki są chętnie stosowane (User Experience in libraries: Applying etnhnography..., 2016). Jak pisze Bryony Ramsden, badaczka zajmująca się stosowaniem metod etnograficznych w bibliotekach, „(...) użytkownicy bibliotek tworzą osobną kulturę, charakteryzują się odrębną tożsamościa, która może dostarczyć nam informacji o ich wzorcach użytkowania [biblioteki]" (Ramsden, 2016, p. 10).

\subsection{MAPOWANIE KOGNITYWNE}

Jest to technika graficzna, mająca swoje korzenie w psychologii. Przy jej pomocy analizuje się relacje między elementami, opisującymi zagadnienie / problem do rozwiązania. W tej technice najważniejsze jest odkrycie, w jaki sposób kolejne etapy badanego procesu wpływają na siebie i jakie występują w nim zmienne niekontrolowane (Sobczak, 2007). Uczestnik badania na kartce papieru opatrzonej nagłówkiem zagadnienia ma za zadanie w krótkim czasie (sześć minut) stworzyć „mapę”, zmieniając co dwie minuty kolor narzędzia do pisania. Kolory to ważny aspekt - każdy z nich oznacza stopień ważności dla badanego. Termin „mapa” to okreś- 
lenie umowne - to, co stworzy badany, może mieć dowolną formę graficzną. Ważnym elementem tego badania jest późniejsza dyskusja: oprócz tego, co zostało zawarte w wypowiedzi badanego, istotne jest również to, co się tam nie znalazło. Technika pozwala na uzyskanie informacji dotyczących nie tylko doświadczeń badanego w korzystaniu z biblioteki, ale również na temat jego funkcjonowania poza nią (Ramsden, 2016, p.15).

Mapowanie kognitywne jest techniką wielokrotnie stosowaną $\mathrm{w}$ bibliotekach na świecie, m.in. w dużym projekcie ERIAL: Ethnographis Research in Illinois Academic Libraries (Asher, Miller, 2011). Przykładowo, jeżeli przedmiotem badania jest przestrzeń, w jakiej studenci spędzają czas ucząc się, informacje o tym, gdzie jeszcze oprócz biblioteki to robią i dlaczego ta przestrzeń jest dla nich ważna, będzie kluczową dla określenia polityki dotyczącej planowania instytucjonalnego (na różnym poziomie) (Lanclos, 2016, s. 33). Istotną kwestią będzie również zadanie właściwych pytań badawczych: w przypadku przestrzeni bibliotecznej mogą one brzmieć nie tylko „Gdzie (w jakiej przestrzeni rzeczywistej) studenci najchętniej się uczą”, ale również „Dlaczego określona przestrzeń w bibliotece nie jest przez nich wykorzystywana?" lub „W jaki nieprzewidziany i niezaplanowany przez nas sposób korzystają z określonej przestrzeni?" (Ramsden, Jensen, Beech, 2015). Interesującym przykładem, oprócz wcześniej wymienionych, jest badanie użytkowników niewielkiej Biblioteki Wolfson College, University of Cambridge (Westbury, 2014), które zaowocowało znacznymi zmianami w organizacji przestrzeni i bardzo ciekawymi spostrzeżeniami dotyczącymi użytkowników. Wspomniane badanie przy użyciu mapowania kognitywnego jest dla nas wartościowe również z innego powodu: pokazuje, że do pogłębiania wiedzy o użytkowniku nie są potrzebne specjalne zasoby finansowe, dodatkowy czas czy specjalne umiejętności. Polityka małych kroków cechuje właściwie całą sferę UX nie chodzi tu o prowadzenie badań w dużej skali, ale raczej o niewielkie działania, które zaangażują bibliotekarza i zaowocują nową motywującą go wiedzą i realnymi zmianami (Schmidt, 2015).

\subsection{SORTOWANIE KART}

Ta technika polega na układaniu przez badanego tematów, zagadnień i innych elementów umieszczonych (przez niego lub wcześniej przygotowanych) na kartkach w zestawienia, zgodne $\mathrm{z}$ własnym zrozumieniem danych. Sortowanie może mieć charakter otwarty (uczestnicy badania sami porządkują karty) lub zamknięty (mają do dyspozycji przygotowane wcześniej grupy lub kategorie) (Nunnally, Farkas, 2017, s. 55). Istnieje także możliwość tworzenia tzw. wolnej listy (Mościchowska, Rogoś-Turek, 2019 s.205), kiedy to badani nadają nazwy kategoriom. Wolna lista może być stosowana jako etap wstępny przed sortowaniem otwartym lub zamkniętym. Sortowanie może być przeprowadzane w niewielkich 
grupach, indywidualnie a nawet zdalnie (przy pomocy specjalnych programów np. Optimal Sort czy Web Sort) (Mościchowska, Rogoś-Turek, 2019, s. 207). Niezwykle ważne jest omówienie (lub tzw. myślenie na głos w trakcie badania) dokonanych podziałów, aby zrozumieć sposób tworzenia grup danych i przesłanki, jakie za nim stoją. Warto zaznaczyć, że tworzone podziały nie mają za zadanie dostarczenia gotowych rozwiązań w zakresie tworzonej struktury - mają być jedynie próbą wskazania przez badanych kategorii danych, które są przez nich uznane za najważniejsze. Te informacje mogą być następnie wykorzystane jako jeden z elementów dalszego projektowania.

Metoda ta może być zastosowana przykładowo przy projektowaniu strony biblioteki (Hepburn, Lewis, 2008), funkcjonalności OPAC lub przestrzeni bibliotecznej.

\subsection{FOTO-PAMIĘTNIKI}

Jest to rodzaj techniki wizualnej i autoetnograficznej, która polega na tym, że badany fotografuje przez określony czasu wybrane aspekty rzeczywistości, w jakiej funkcjonuje. Technika foto-pamiętników może być niezwykle użyteczna dla bibliotekarza - poznanie nawyków, postaw, motywacji i zachowań użytkownika poza biblioteką oznacza właśnie wspomniane wcześniej określenie, czy i w jaki sposób biblioteka wpisuje się ze swoją ofertą w jego podróż do wiedzy.

Trzeba zaznaczyć, że tego typu badanie nie może zawierać wcześniej przyjętej hipotezy lub pytania badawczego (Banks, 2009, s. 32) Jest to rodzaj techniki eksploracyjnej, która ma na celu rozpoznanie do tej pory niezbadanego wycinka rzeczywistości, w której porusza się użytkownik.

Po wykonaniu zdjęć badany ma za zadanie opowiedzieć o tym, co przedstawiają. Przykładem takiego działania było prowadzenie foto-pamiętników związanych z miejscem do nauki w czasie całego semestru przez amerykańską Bibliotekę J. Murrey Atkins (Lanclos, 2016, p. 25 ). Obserwacje na podstawie zebranych zdjęć pozwoliły m.in. na stwierdzenie, że podczas nauki studenci nie tylko korzystają z krzeseł czy foteli, ale w trakcie pisania prac korzystają z kanap a nawet łóżek. To zróżnicowanie miejsc nauki dało impuls do wprowadzenia zmian w przestrzeni bibliotecznej. Foto-pamiętniki to technika, która może być częścią większego badania określanego „sondą kulturową” (Cultural Probe), w ramach którego badany zbiera dane jednocześnie poprzez różne kanały np. nagrania dźwiękowe, wideo, pisanie notatek (Forsberg, 2017, p. 133).

\subsection{SONDA KULTUROWA}

Jak już wspomniano wyżej technika ta jest wielokanałowym badaniem użytkownika, mającym na celu zaangażowanie go w badanie, a jednocześnie pobudzenie jego kreatywności i autorefleksji. Sonda kulturowa może 
łączyć w dowolny sposób inne techniki UX, aby poszerzyć obraz użytkownika o różne perspektywy i punkty widzenia.

Niezwykle interesująca sonda kulturowa została przeprowadzona na Uniwersytecie Cambridge w ramach projektu Snapshot (Migawka) (Priestner, Marshall, 2016) badającego osoby po doktoracie (tzw. post-doców) tej uczelni (reprezentujące różne dyscypliny, zarówno nauki ścisłe, jak i humanistyczne). Każdy z badanych otrzymał pakiet materiałów, w których znalazły się takie elementy jak: dziennik zawierający pytania na każdy dzieńn ${ }^{3}$ koperty z zadaniami (które uczestnik miał otworzyć w określonych dniach trwania badania), materiały do mapowania kognitywnego, pendrive do zapisywania zdjęć (robienie ich było jednym z zadań z koperty) ${ }^{4}$. Do zadań należało również napisanie „Listu miłosnego / zrywającego" (o tej technice poniżej).

Warto podkreślić, że projekt Snapshot był projektem otwartym, nie stawiającym na wstępie hipotez badawczych. W tym sensie można powiedzieć, że tego typu badanie dokładnie pokazuje, czym jest UX. Wyniki, jakie uzyskali prowadzący badanie, były bardzo ciekawe oraz inspirujące (Priestner, Marshall, 2016, s. 20). W zdecydowany sposób wpłynęły na zmiany w sposobie patrzenia na usługi biblioteczne przez samych bibliotekarzy. Jest to wartość dodana, której nie dałoby się pozyskać poprzez ankiety czy badania ilościowe.

\subsection{LIST MIŁOSNY / ZRYWAJĄCY}

Zabieg antropomorfizacji biblioteki poprzez pisanie krótkich tekstów w formie "listu miłosnego" wyrażającego to, co wg badanego jest najbardziej przez niego doceniane lub w formie "listu zrywającego", który mówi o tym, co użytkownikowi najbardziej przeszkadza i jest powodem dla unikania kontaktu z biblioteką. Biblioteka jest w tych tekstach osoba, do której bezpośrednio zwraca się badany. Forma wypowiedzi to listy/ kartki, które badany wrzuca do skrzynki (Green, 2012) lub zapis na przygotowanych tablicach. Technika ta może być rozszerzana o inne sposoby otrzymania treści (np. poprzez media społecznościowe, stronę www itp.). Listy mogą być skierowane nie tylko do biblioteki jako takiej, ale dotyczyć jej usług bądź innych aspektów działalności (np. działania katalogu bibliotecznego czy organizacji przestrzeni).Niewątpliwą zaletą tej techniki jest jej prostota.

W Polsce podjęto próbę takich badań w Centrum Informacyjno-Bibliotecznego Uniwersytetu Medycznego w Łodzi (Milewska, 2018). Tego typu

${ }^{3}$ Przykładowe pytania i zagadnienia: „Co motywuje/demotywuje cię do prowadzenia badań?” „Opowiedz o swoich przerwach w pracy. Jak długo trwają? Jak spędzasz podczas nich czas? Jaki mają wpływ na twoją pracę?"

${ }^{4}$ Zdjęcia również miały określone tematy np. „Jak wygląda sukces?” "Jak wygląda porażka?" „Coś, co pomaga ci przetrwać dzień." „Coś inspirującego." „Coś zaskakującego." 
działanie odgrywa szczególną rolę w budowaniu empatii i projektowaniu spersonalizowanych usług, ponieważ pozwala uchwycić zagadnienia dla użytkowników najważniejsze z ich punktu widzenia (Martin, Hanington, 2012, s. 114).

\section{PODSUMOWANIE}

Techniki przedstawione $\mathrm{w}$ tekście to jedynie próba przedstawienia możliwości, jakie stwarza stosowanie UX w bibliotekach. Ich cechą wspólną jest przede wszystkim zaangażowanie użytkowników. Każda z nich $\mathrm{w}$ inny sposób włącza badanych w organizację biblioteki i daje im poczucie realnego wpływu na to, jak będą wyglądać usługi biblioteczne, z których korzystają. Mnogość przykładów zagranicznych ${ }^{5}$ dobitnie pokazuje, że UX w bibliotekach już od lat ma się dobrze i daje doskonałe wyniki w postaci usług skrojonych na miarę ich użytkowników. Co więcej, przedstawione techniki mogą być ze sobą łączone na rozmaite sposoby, dostosowując się do realiów określonej biblioteki.

W Polsce, poza nielicznymi wyjątkami techniki UX nie są stosowane ${ }^{6}$, choć temat UX zaczyna pojawiać się $\mathrm{w}$ referatach i artykułach ${ }^{7}$. Można zadać pytanie, dlaczego tak słabo są $\mathrm{w}$ naszym kraju wykorzystywane? Czy problemem jest skracanie dystansu między bibliotekarzem a użytkownikiem, co wymaga umiejętności interpersonalnych, których brakuje polskim bibliotekarzom? Czy też powodem jest lęk przed „nieznanym”? Problem może być bardziej złożony i dotyczyć po pierwsze faktu, że badania jakościowe trudno jest ubrać w liczby i słupki, a jak pisze Andy Priestner (Priestner, 2017, s. 7) (...) w UX chodzi właśnie o niewiadoma, o to, że nie wiesz, co odkryjesz i jest to jak najbardziej prawidłowe (...). A przecież jeśli otrzymujemy dane ilościowe $\mathrm{w}$ wyniku badania statystyk oraz ankiet, badania jakościowe mogą zweryfikować otrzymane informacje w przykładach z życia wziętych (Appleton, 2017).

Drugą kwestią jest niewiedza, czym jest UX i słaba orientacja w sposobie prowadzenia badań oraz analizowania ich wyników (co jest odrębną kwestia, nieujętą $w$ niniejszym artykule, ale nie mniej istotną). Inną sprawą jest czasochłonność i zapewnienie odpowiedniej obsady do prowadzenia badań, podczas gdy trzeba zapewnić bieżącą obsługę użytkowników. Przekładając to na polskie realia, być może konieczne byłoby upowszechnienie wiedzy o tym, czym tak naprawdę są takie badania wśród kadry

\footnotetext{
${ }^{5}$ Wiele z doświadczeń bibliotecznych zakresie UX jest prezentowana rokrocznie na konferencji i warsztatach UXLibs: www.uxlibs.org

${ }^{6} \mathrm{~W}$ Bibliotece Jagiellońskiej prowadzony jest pilotaż badań UX, ale brak szczegółów dotyczących tego projektu.

${ }^{7}$ Małopolskie Forum Bibliotek w 2019 r. było poświęcone zagadnieniom UX w bibliotekach.
} 
decyzyjnej polskich bibliotek, aby oswoić UX na rodzimym gruncie i pokazać, jakie korzyści przynoszą.

UX to również zaproszenie do dyskusji, w jaki sposób wprowadzać w bibliotekach nowości związane z aranżacją przestrzeni realnej czy wirtualnej, a także w jaki sposób dokonywać ewaluacji funkcjonujących już rozwiązań. Z pewnością stosowanie technik UX może odpowiedzieć na wiele pytań, które chcielibyśmy zadać użytkownikom bibliotek, również na takie, które nigdy nie pojawiłyby się, gdyby nie użytkownik, który nas na nie naprowadził. Gratyfikacją jednak jest wiedza, której nie da się ujać liczbami, a która nada naszym usługom bibliotecznym "ludzką twarz". I pod tym względem jest to niezaprzeczalna wartość UX.

\section{BIBLIOGRAFIA}

Angrosino, Michael (2010) Badania etnograficzne i obserwacyjne. Warszawa: Wydaw. Naukowe PWN.

Appleton, Leo (2016) User Experience (UX) in Libraries: Let's Get Physical (and Digital). Insights [online] 29 (3): 224-27. [dostęp: 20.08.2019]. Dostępny w WWW: https://insights.uksg.org/articles/10.1629/uksg.317/.

Appleton, Leo (2017) Qualitative methods for engaging students in performance measuement. Information and Learning Science. Vol. 119, no. 1/2, s. 64-76.

Asher, Andrew; Miller, Susan (2011) So you want to do anthropology in your library? or A Practical Guide to Ethnographic Research in Academic Libraries [online], [dostęp: 20.08.2019]. Dostępny w WWW: http://www.erialproject.org/wp content/ uploads/2010/05/Toolkit_Draft_1.pdf.

Banks, Marcus (2009) Materiały wizualne w badaniach jakościowych. Warszawa: Wydaw. Naukowe PWN.

Derfert-Wolf, Lidia; Sobielga, Jolanta; Strzelczyk, Edyta; Zawałkiewicz, Aldona (2018) Ogólnopolskie badania satysfakcji użytkowników bibliotek szkót wyższych $w 2017$ r. [online]. Stowarzyszenie Bibliotekarzy Polskich [dostęp: 20.08.2019], Dostępny w WWW: http://pliki.sbp.pl/afb/afbn/new/Sprawozdanie_akademickie_2018.pdf.

Flick, Uwe (2010) Projektowanie badania jakościowego. Warszawa: Wydaw. Naukowe PWN.

Forsberg, Åsa (2017) Basing arguments on evidence: the unexpected outcome of a cultural probe. In: User Experience in Libraries: [stories, techniques, insights]. Yearbook 2017 edited by Andy Priestner, pp. 132-136.

Friberg, Anneli (2017). Why continuous usability testing can and should be part of regular library activity - from UXlibrarian's point of view. Revy, no. 1, pp. 9-11.

Green, Clare (2017) Love and brek-up letters to the Library. [online], [dostęp: 20.08. 2019]. Dostępny w WWW: https://blogs.kent.ac.uk/isux/2017/02/21/love -and-break-up-letters-to-the-library/.

Gullikson, Shelley; Meyer, Kristin (2016) Collecting Space Use Data to Improve UX in Library Space. Weave. Journal of Library User Experience [online], vol.1, nr 5 [dostęp: 20.08.2019]. Dostępny w WWW: https://quod.lib.umich.edu/w/ 
weave/12535642.0001.502/-collecting-space-use-data-to-improve-the-ux-oflibrary-space?rgn=main;view=fulltext; 1 =behavioral.

Hald, Peter; Just Nordholdt, Melissa (2018) Comparative study of UX and sensor data from the perspective of behavioural mapping. In User Experience in Libraries: [inclusivity, diversity, belonging]. Yearbook 2018 edited by Andy Priestner, p. 210-215.

Hepburn, Peter; Lewis, Krystal M. (2008) What's in a Name? Using Card Sorting to Evaluate Branding in an Academic Library's Web Site. College and Resarch Libraries, May, pp. 242-249.

Jasiewicz, Justyna (2018) Eyetracking i facetracking rękopisów iluminowanych. Potencjał zastosowania metod badań biometrycznych w bibliologii. Naukowy Przegląd Dziennikarski nr 3, s. 27-50.

Kamińska, Anna (2017) Badanie satysfakcji użytkowników Biblioteki Politechniki Śląskiej w Gliwicach. Raport dla użytkowników. [online], [dostęp: 20.08.2019]. Dostępny w WWW: https://www.polsl.pl/Jednostki/RJO1BG/Documents/Dokumenty\%20tekstowe/raport_badanie_satysfakcji.pdf.

Kołakowska, Joanna (2008) Badanie potrzeb użytkowników biblioteki. Annales Academiae Paedagogicae Cracoviensis. Folia 61 Studia ad Bibliothecarum Scientiam Pertinentia VI s. 128-137.

Kostera, Monika (2003) Antropologia organizacji. Metoda badań terenowych. Warszawa: Wydaw. Naukowe PWN.

Kostera, Monika; Krzywokrzeka, Paweł (2012) Etnografia. W: Badania jakościowe i obserwacyjne. Podejścia i teorie. T. 1. Red. Dariusz Jemielniak. Warszawa: Wydaw. Naukowe PWN, s. 167-187.

Krug, Steve (2005) Nie każ mi myśleć! O życiowym podejściu do funkcjonalności stron internetowych. Gliwice: Helion.

Lanclos, Donna M. (2013) The Anthropologist in the Stacks: Playing with Cognitive Mapping: [online], [dostęp: 20.08.2019]. Dostępny w WWW: http://atkinsanthro.blogspot.com/2013/11/playing-with-cognitive-mapping.html.

Lanclos, Donna M (2016) Embracing an ethnographic agenda: context, collaboration and complexity In: User Experience in Libraries: Applying Ethnography and Human-Centered Design. Edited by Andy Priestner and Matt Borg, pp. 21-37.

Lipiec, Maciej (2007) Architektura pozytywnych doświadczeń. [online], [dostęp: 20. 08.2019]. Dostępny w WWW: https://uxdesign.pl/architektura-pozytywnych -doswiadczen.

Martin, Bella; Hanington, Bruce (2012) Universal Methods of Design: 100 ways to Research Complex Problems, Develop Innovative Ideas, and Design Innovative Solutions. Beverly, Mass.: Rockport.

McLauglin, Juliene; Rayment, Erik (2018) Touchstone Tours UX Study - Final Report. [online], [dostęp: 20.08.2019]. Dostępny w WWW: https://atrium.lib. uoguelph.ca/xmlui/bitstream/handle/10214/14759/Touchstone_Tours_UX_ Study_Final_Report.pdf?sequence $=1 \&$ isAllowed $=\mathrm{y}$.

Milewska, Paulina (2018) Co myślą użytkownicy bibliotek? Refleksje po badaniach użytkowników Centrum Informacyjno-Bibliotecznego Uniwersytetu Medycznego w Łodzi Biuletyn EBIB, nr 5 (182) [online], [dostęp: 20.08.2019]. Dostępny w WWW: http://open.ebib.pl/ojs/index.php/ebib/article/view/659/802.

Morville, Peter; Rosenfeld, Leo (2003) Architektura informacji serwisach internetowych. Gliwice: Helion. 
Mościchowska I.; Rogoś-Turek B. (2019) Badania jako podstawa projektowania User Experience. Warszawa: PWN.

Norman, Don; Nielsen, Jacob The Definition of User Experience (UX) [online], [dostęp: 20.08.2019]. Dostępny w WWW: www.nngroup.com/about/userexperience.html.

Nunnally, Brad; Farkas, David. (2017) Badanie UX. Praktyczne techniki projektowania bezkonkurencyjnych produktów. Gliwice: Helion, O’Reilly.

Poniatowski, Bartosz (2016) Wykorzystanie mapowania behawioralnego w projektowaniu i ewaluacji przekształceń przestrzeni publicznych. Studium przypadku Placu Wolności w Łodzi. Studia KPZK, nr 168, s. 158-173.

Priestner, Andy; Borg, Matt (2016) ed. User Experience in Libraries: Applying Ethnography and Human-Centered Design. New York: Routledge.

Priestner, Andy; Marshall, David (2016) Snapshot: A cultural probe study exploring the research and information behaviour of postdocs and PhD students at the University of Cambridge. [online], [dostęp: 20.08.2019]. Dostępny w WWW: https:// futurelib.files.wordpress.com/2016/09/the-snapshot-project.pdf.

Priestner, Andy (2017) Approaching maturity? UX adoption in libraries. In: User Experience in Libraries: [stories, techniques, insights]. Yearbook 2017, ed. by Andy Priestner. Cambridge: UXlib.

Priestner, Andy (2018) Behavioural mapping: decisions and desires. [online], [dostęp: 20.08.2019]. Dostępny w WWW: https://andypriestnertraining.files. wordpress.com/2019/08/ipm-behaviouralmapping.pdf

Ramsden, Bryony (2016) Using ethnographic methods to study library use. In: User Experience in Libraries: Applying Ethnography and Human-Centerd Design. Edited by Andy Priestner and Matt Borg. pp. 9-20.

Ramsden, Bryony; Jensen, Kathrine; Beech, Megan (2015) Cognitive mapping and collaborating. [online], [dostęp: 20.08.2019]. Dostępny w WWW: https://ukanthrolib.wordpress.com/2015/11/16/cognitive-mapping-and-collaborating/

Schmidt, Aaron (2015) The User Experience. UX means You. Library Journal, October 1, pp. 21.

Sobczak, Andrzej (2007). Zastosowanie rozmytych map kognitywnych w planowaniu rozwoju zorientowanej na usługi architektury systemów informatycznych. W: Zarzadzanie rozwojem organizacji. Pod red. Stefana Lachiewicza Tom 1, Łódź: Wydaw. Politechniki Łódzkiej, s. 592-601.

Stiles, Keren (2017) UX research with distance learners. In: User Experience in Libraries: [stories, techniques, insights] edited by Andy Priestner. pp. 127-131.

Strzelczyk, Edyta; Zawałkiewicz, Aldona (2018) Jak przeprowadzić badania satysfakcji użytkowników biblioteki? Poradnik dla bibliotekarzy, [online], SBP [dostęp: 20.08.2019]. Dostępny w WWW: http://pliki.sbp.pl/afb/jak-przeprowadzic-badania-satysfakcji.pdf.

Westbury, Meg (2014) Students these days, Part 1 [online], [dostęp: 20.08.2019]. Dostępny w WWW: https://ukanthrolib.wordpress.com/2014/05/27/studentsthese-days-part-i/.

Westbury, Meg (2014) Students these days, Part 2 [online], [dostęp: 20.08.2019]. Dostępny w WWW: https://ukanthrolib.wordpress.com/2014/06/03/studentsthese-days-part-ii/.

Wu, Kim Somaly; Lanclos, Donna (2011) An ethnographic approach to web usability and space design. Reference Service Review. Vol. 39, nr 3. pp. 369-389. 
Wolańska, Agnieszka (2018) Metoda etnograficzna i UX usability testing w badaniach użytkowników bibliotek. Badania jakościowe kontra kult statystyki. Annales Universitatis Paedagogicae Cracoviensis. Folia 257. Studia ad Bibliothecarum Scientiam Pertinentia 16, s. 220-235.

Wójcik, Magdalena (2016) Ekonomia doświadczeń a usługi informacyjne. Bibliotheca Nostra. Ślaski Kwartalnik Naukowy, nr 2 (44), s. 101-111.

Artykut w wersji poprawionej wptynat do Redakcji 16 stycznia 2020 r.

AGNIESZKA WOLAŃSKA

Willy Brandt Center for German and European Studies

University of Wrocław

e-mail: agnieszka.wolanska@uwr.edu.pl

\section{HEAR THE UNSPOKEN, NOTICE THE UNSEEN. UX (USER EXPERIENCE) TECHNIQUES IN LIBRARY USER RESEARCH. OPPORTUNITIES AND PERSPECTIVES}

KEYWORDS: Library. User research. Qualitative research. UX. User experience. UX techniques. Cognitive mapping. Behavioral mapping. Card sorting. Cultural probe. Interview. Attitude research. Behavior research. Touchstone tours. Observation.

ABSTRACT: Thesis/Objective - If one builds his knowledge of library users with most frequently employed surveys or structured interviews, in many cases he misses the full picture of the user's real intentions and needs. According to the anthropologist Margaret Mead "What people say, what they do and what they say they do, these are three completely different things." The author focuses on UX techniques used to discover the unseen and unspoken user needs and discusses the possibility of implementing the research with the use of those techniques in Polish environment. Research methods - The author analyzed English and Polish literature on UX techniques published in the last decade and referred to earlier publications in the field of ethnology and anthropology, the disciplines tightly related to qualitative research. The analysis shows that UX in libraries is usually discussed in the context of foreign institutions, remaining virtually non-existent in Polish literature of the field. The author used analyzed sources to present a spectrum of UX techniques with respective examples. She confirmed her conclusions with experience acquired at UXLibs workshop run in Sheffield in 2018. Results and conclusions - UX techniques presented in the article prove to be useful in international library research and data obtained that way may significantly enhance quantitative research, so far prevailing in Polish library environment. 